\title{
NEW LITERARY VIEWS ON THE THEME OF WAR IN UZBEK LITERATURE
}

\author{
Oybek Umarjon Ugli Kholmatov
}

Researcher, Fergana State University, Uzbekistan

\section{ABSTRACT}

In Uzbek literary studies, the article analyzes the question of updating literary and theoretical viewpoints on the topic of war. The scientific viewpoints of a number of scientists and writers were used in principle. The major goal of this article is to examine how Uzbek literature interprets the Second World War and the Afghan war, as well as to conduct a scientific examination of works on the subject by literary critics. Scientific sources on the subject are employed in the analysis, which is based on opinions and viewpoints.

KEYWORDS: - Military Literature, war, prose, story, military novel, analysis, interpretation.

\section{INTRODUCTION}

By the twentieth century, the anti-war mood and the tide of pacifism had taken center stage in Western literature. Only black paints were used to depict the war, which was a source of sorrow and disaster. In the twentieth century, Uzbek literature got a similar interpretation. However, the image of the heroes, who demonstrated heroism both behind and in front of the front lines, persisted. If the tragic spirit reigns supreme in works depicting the themes of the First World War and the Afghan war, patriotism and heroism are represented in works depicting the subjects of the Second World War. These difficulties drew the attention of literary critics as well. S.Mamajanov, N.Bekmirzayev and after such scientists as A. Yuljaboev, in Uzbek literature on the theme of the war in the interpretation of H. Karimov, B. Nazarov, U. Normatov, X. Hamroqulova, Q.Yoldoshev scientists and writers as S. Polatov described their own image and literary views. Their new views changed the issue of attitude to the war in Uzbek literature.

\section{Methods}

For many years, works in Uzbek literature from the twentieth century that deal with the Second World War have been studied from the perspective of communist ideology. However, in the years since independence, public opinion on the war's issue has shifted dramatically. The philosophy of pacifism, which rejected any appearance of conflict, now took center stage. "Even in works made during the conflict, the truth of life did not find its truth," writes literary critic Hakimjon Karimov in this regard. "The battleground is changing. Even in the 
CURRENT RESEARCH JOURNAL OF PHILOLOGICAL SCIENCES 2(11):

90-93, November 2021

DOI: https://doi.org/10.37547/philological-crjps-02-11-20

ISSN 2767-3758

(C)2021 Master Journals

\section{Crossref dol 81 Google}

Accepted25 $5^{\text {th }}$ November, 2021 \& Published $30^{\text {th }}$ November, 2021

formation of the image of the adversary - the Germans - they were viewed through the prism of socialist society's ideology, and they were represented as simple and relaxing, which was completely at odds with reality." [4: 1] Indeed, there are numerous circumstances such as one-sidedness, the absolutization of positive or negative attributes in the heroes threeraydi in the works made on this subject throughout the war years and several decades afterward. This diminishes the objectivity trait of equity, which is a fundamental requests of epic works.

The process of changing the attitude towards the Second World War in the Uzbek prose is evident through the analysis of the works of K. Hoshimov on this topic. In this light, the narrative "the final war victim" and the novel "between the two doors" are particularly significant. A literary critic named A.Kayumav comes to mind. The work emphasizes that 0'. Hoshimov's story "the last victim of the war" reflects the process of national character destruction against the backdrop of the war's terrible consequences, and that the difficulties of the war period against the backdrop of the heroes' actions and relations had a negative impact on family relations, [2: 59] in fact, every detail in the story, every image serves to reflect a certain traced. If the negative consequences of the war are reflected on the example of the fate of one family in the narrative "the last victim of the war," then this process is portrayed in the novel "between the two doors" through the image of the terrible fate of an entire community. The evolution of this trait is heavily influenced by negative heroes. In this way, Umar Zakunchi's image is emblematic. Academician Bakhtiyor Nazarov, commenting on the novel's role of this play, stated that the image of Umar zakunchi played a significant part in revealing the true vices of the time: "the writer did not hesitate to reproach that he did not raise a little in criticizing the appearance of some of our compatriots during the war, Umar zakunchi such an interpretation of the hero added to the novel. Because the writer did not retreat from the truth of life." [3: 31] 0'. Hoshimov expressed the destructive essence of the war in a truthful way, emphasizing its destructive character, opened a new way in the Uzbek military prose on the issues of image and interpretation.

Writing criticism has reflected shifts in attitudes toward war in the literary process. In her dissertation "The Problem of Life or death in Literature," Khurshida Hamroqulova, in particular, draws attention to the scale of tragedies mirrored in artistic works, namely those on the theme of war. When thinking about Esonkul's "people of War," The Look considers the fate of the work's heroes, who were affected by the war's negative effects and thus met a tragic end: "the misfortune of Anzirat in the face of his cruel fate, the uncertain fate of children, the superiority of or over kindness, the tragedy of the norm." [4: 136] The researcher approaches the issue on the basis of the motive of death, emphasizing that war was a major factor in the tragic death of the heroes of the work. It is worth adding that in most of the works on the theme of the war, written in the years of independence, the scale of tragedy is heavier than heroism. And this means that in today's literature, the attitude to the Second World War has also changed.

With a comparative analysis of the works of Chingiz Aytmatov "Face to face," Said Ahmad "Horizon," and Valentin Rasputin "Do not forget if you survive", Sh. Abdugapparova focuses on the interpretation of tragedy in the approach to the image of combat veterans. "In all three works, the sad images of the struggle that led to the creation of mankind, the enjoyment of innocent people's lives, the great losses and blows brought to Man's spiritual world, the heroes of the work: Ismail ("Face to face") Tursunboy ("Horizon") - [5: 72]. The researcher 
CURRENT RESEARCH JOURNAL OF PHILOLOGICAL SCIENCES 2(11):

90-93, November 2021

DOI: https://doi.org/10.37547/philological-crjps-02-11-20

ISSN 2767-3758

(C)2021 Master Journals

\section{Crossref doi 81 Google}

Accepted25 $5^{\text {th }}$ November, 2021 \& Published $30^{\text {th }}$ November, 2021

focuses more on the issue of the damage caused by war to the spirituality of Man and society rather than the violation of loyalty to military duty. Through this, the war assumes that courage is not a test of courage, but a destructive and destructive phenomenon.

Among the works that have been recognized in modern literature as a war-torn phenomenon, writings on the Afghan war are particularly notable. In contrast to works on the theme of the Second World War, there is a question of approach to war in works on the theme of "Afghan." That is, all authors reflect the stroke in black paint as a cause of death and sadness in all works on this theme. This feature is well-emphasized in literary criticism. "The story cannot be read without immense thrill," he adds in response to Ahmed's description of sharp Hoshimov's work as "living in a dream." He shook the reader's hand. The Mad Warriors, who start a bloody battle, which has nothing but trouble on the head of the people, pour out a curse from their hearts." [6:228] He wanted to convey in the story that the spirit of nonviolence is a priority by underlining that Saidahmad was viewed as a source of sorrow. In addition, literary scholar Umarali Normatov observes a meeting of existentialism's features in the novel "past lives in a dream." [4: 7] The preceding points also demonstrate. In 0 '. Hoshimov's novel "The Past Lives in a Dream," the conflict has only a negative impact on the heroes' fate. The Spirit of utter reluctance to battle triumphs in this story.

Gafur Polatov's autobiographical novel "Herirud wail" established a new standard in Uzbek military language. This work was reprinted as a military field novel by the publishing house "Navruz" in 2018. It was first published in the magazine "world literature" and afterwards in numerous publications as a military field story. The author draws a clear eye from the introduction, watered by the pacifist spirit of the work, the notion of hatred for war: "every conflict, whether huge, tiny, fair or unfair, is a brine that falls on the forehead of mankind." The Shur - Afghan conflict was one such shurpeshona war that took place in the last quarter of the twentieth century. [8: 3] The author criticizes any strike based on the Afghan conflict. At the same time, the author appears in the preface as a critic, assessing the issue of the interpretation of the Afghan war in contemporary Uzbek literature: "it is gratifying that modern Uzbek literature remains the country of prose in the CIS countries that has most touched upon the topic of the Afghan." The Russian released literature on the Afghans as well. However, there is a strong desire to justify the previous conflict in Russian works and a salty soldier's invading visit. [8: 4] Adib devotes special emphasis to the approach to the Afghan war in the preceding phrases. In Uzbek literature, the works on the topic "Afgan " are in a pacifist spirit, in addition to emphasizing that the original essence of the Afghan war is revealed by means of images, in Russian literature this approach to war is different. These analyzes are also significant with their comparative aspect.

The novel "The smell of blood" by another writer Abdurashid Normurodov, who worked on the topic of the Afghan war, is also rated as a work that condemns the beating in literary criticism. In particular, Hakimjon Karimov writes about the novel: "all the horrors, complexities of the Afghan war, which arose on the basis of absurdity in the novel, have expressed themselves in the variety of appearances." [1: 108]

The Critic clearly showed the spirit of condemning the hit in the work by emphasizing that his war expressed in the novel was of absurd essence. In the process of analyzing the novel "The smell of blood," another scientist Kazak Yoldoshev uses the term "alienated generation" in relation to Afghan war 
CURRENT RESEARCH JOURNAL OF PHILOLOGICAL SCIENCES 2(11):

90-93, November 2021

DOI: https://doi.org/10.37547/philological-crjps-02-11-20

ISSN 2767-3758

(C2021 Master Journals

Crossref do

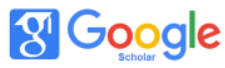

Accepted25 $5^{\text {th }}$ November, 2021 \& Published 30th November, 2021

participants: "If Hemingway and Remark wrote a pen about the" Lost Generation," then Abdurashid Normurodov created the embodiment of an alienated generation, both from himself and from other people." (9: 7) This theory is founded on the fact that the "Lost Generation" qualities, which were popular in Western literature in the 20th and 30th centuries, were reflected in works about the Afghan conflict. It is conceivable to completely agree with the scientist's viewpoint. Because Uzbek writers' works on the Afghan war are ideologically similar to American and European writers' works on the generation of young people who perished or whose lives were ruined as a result. Both sorts of works have in common that they describe the tragic fate of the younger generation who is a participant in the war.

\section{Conclusion}

Based on the foregoing research, it is feasible to conclude that the issue of the "Lost Generation" has arisen even in modern Uzbek military literature, on the basis of which works on the Afghan war have been written.

Modern Uzbek literary studies, on the whole, are evolving in lockstep with the literary process. In the process of analyzing works on the topic of war, this process is clearly obvious. The attitude toward the war phenomena is expressed in new ways in artistic literature, as well as in literary criticism.

\section{REFERENCES}

1. Karimov H. Uzbek novels promotion of princeples development. - Tashkent, 2008.

2. Kayumov A.A. Now the Uzbek Nazi character is a militant and artistic skill (he or she). Khoshimov and N.Zhalliddin an approximate story). Phil. F. B. fals. doctor (PhD) dissertation. - Fergana, 2018.
3. Nazarov B. Elevschining spiritual jasming. // "Uzbek language and literature" journal, 2011 / No. 3" - 27-31 p

4. Khamrokulova $\mathrm{H}$. The life or death of literature. - Tashkent, 2009.

5. Abdugapparova Sh. The fate of man. // "Uzbek language and literature" journal. 2016, No. 3. 72-75 p.

6. Ahmad S. "What I lost and what I found". Toshkent: "SHARQ", 2000

7. Normatov U. Today's admitted to being deceived by princseples. // " Uzbek language and literature " journal, 2001 / No. 3. - 3-9. p

8. Po'latov G'. "Herirud wail"- - Toshkent: "Navro'z", 2018.

9. Q. Yo'ldoshev. Recovery Suffering bites. // Normurodov A. The smell of blood. - Tashkent: "Zabarjad Media", 2020. - 4-9 bet.

10. Kholmatov, O. U. U. (2020). Interpretation of" lost generation" in the creation of Erih Maria remark. ACADEMICIA: An International Multidisciplinary Research Journal, 10(11), 1654-1659

11. Kholmatov, O.U.U. (2021). The Image of War People In The Stories Of Utkir Hoshimov. The American Journal of Social Science and Education Innovations, 3(03), 255-260.

12. Kholmatov O.U.U. (2021). Study of the Theme of War in Uzbek Literature. EPRA International Journal of Multidisciplinary Research (IJMR), $7(05), 627-629$. 